\title{
Environmental law and reconciliation with a representative of power under criminal law of Russia
}

\author{
Sergey Zakharchuk ${ }^{1, *}$ \\ ${ }^{1}$ Tyumen Institute for Advanced Training of Employees of Ministry of Internal Affairs of Russian \\ Federation, Amurskaya str., 75, Tyumen, 625049, Russia
}

\begin{abstract}
Domestic criminal legislation provides for possibility of releasing from criminal liability a person who has committed a crime of small or medium gravity for the first time, provided that he/she has reconciled with the victim and made amends for the harm caused. Comparative legal analysis shows that similar norms are found in the criminal laws of foreign states. The article discusses issues related to the possibility of terminating a criminal case in connection with the reconciliation of parties in the event that a victim is a representative of authorities. As a result of analysis of scientific positions on this issue, as well as corresponding law enforcement practice, ambiguity in approaches to its solution was revealed. The presence of certain contradictions in the area under study is also confirmed by statistical information. The author substantiates the position on the need to establish a ban on exemption from criminal liability in connection with reconciliation with the victim, if a crime is committed against justice or the order of administration, and the victim is a representative of authorities. In this case, the victim acts as an additional objective manifestation of encroachment, and therefore, reconciliation cannot eliminate the harm done to the interests of the state the main object of criminal encroachment. In order to resolve the problem, it is proposed to amend Article 76 of Criminal Code of Russian Federation.
\end{abstract}

\section{Introduction}

The modern Criminal Code of Russian Federation, being a normative legal act containing peremptory norms in its content, also has "dispositive" principles. In the criminal law of Russia, "dispositive" principles include the freedom of persons to exercise their rights, in particular the right to reconciliation (Article 76 of Criminal Code of Russian Federation Exemption from criminal liability in connection with reconciliation with the victim). A.V. Sumachev contributed to significant development of this term in criminal law [1].

Analysis of normative legal acts, materials of law enforcement practice, as well as points of view of representatives of scientific community indicates that the institution of reconciliation is developing significantly. However, it is necessary to develop a theoretical,

\footnotetext{
${ }^{*}$ Corresponding author: a.copytowa@yandex.ru
} 
regulatory and methodological basis for the implementation of this institution in practice. Since in law enforcement there are problems of releasing a person from criminal liability in connection with reconciliation with the victim. These problems are conditioned by the variety of positions of scientists and contradictory judicial practice on this issue.

It should be noted that the issues of reconciliation are enshrined, including in the legislation of certain foreign states. In particular, the Penal Code of Federal Republic of Germany in Chapter Two Imposition of punishment in paragraph 46a (Agreement between the person who committed the act and the victim. Compensation for harm) establishes that if the person who has committed the punishable act.

1. seeking to reach an agreement with the victim (agreement between the person who committed the act and the victim - Tater-Opfer-Ausgleich), compensates in full for the harm or a significant part of the harm caused by his act, or seriously seeks to compensate for the harm, or

2 . in the event that compensation for damage required from him significant personal costs or personal refusal of something, and he compensates the victim for the damage in full or most of it, then the court on the basis of $\S 49$, 1, may mitigate or waive the punishment, unless a more severe punishment is provided than imprisonment for up to one year or a fine of up to 360 monetary rates.

In turn, in the science of criminal law of Federal Republic of Germany, reconciliation with a victim is understood as a proposal sent to the victim and the criminal through professional extrajudicial cooperation to find a mutually acceptable solution to resolve the conflict that has arisen and its resolution.

Criminal Code of France in Book One in Subsection 6. - Release from punishment and postponement of imposition of punishment in Art. 132-58 found that in cases of misconduct, as well as in cases of violations, with the exception of cases provided for in Articles 132-63 to 132-65, the court found the defendant guilty and, if necessary, made a decision to confiscate dangerous or harmful items and substances, has the right to either release the accused from any other punishment, or to postpone the imposition of punishment in the cases and under the conditions provided below.

Simultaneously with the conviction of the defendant guilty, the court makes a decision on the civil claim, if any.

$\S 1$. Release from punishment Art. 132-59. - Release from punishment can take place in the case when the social rehabilitation of the perpetrator is achieved, the damage caused is compensated and the harmful consequences caused by the criminal act have ceased to be effective.

In science in this regard, it is noted that in the cited norm we are talking about certain conditions for release from punishment. The first of the conditions is the resocialization of the culprit. From the point of view of French jurists, this is a reassessment of views and values. The court establishes the existence of a revaluation by carefully examining the personality of the defendant. The second condition is compensation for damage (no claim for full compensation). The form of compensation is possible both in kind and restitution, that is, equivalent monetary compensation. And, finally, the third condition: the need to eliminate violations - the consequences of the committed act.

In turn, in accordance with Art. 76 of Criminal Code of Russian Federation, a person who first committed a crime of small or medium gravity may be released from criminal liability if he/she reconciled with a victim and made amends for the harm caused to the victim. 


\section{Methods}

In accordance with Part 1 of Art. 42 of Code of Criminal Procedure of Russian Federation, a victim is a natural person who has suffered physical, property, moral harm by a crime. The decision on recognition as a victim is taken immediately from the moment of initiation of a criminal case and is formalized by a decision of an inquiry officer, investigator, judge or a court ruling.

The specified definition considers the victim as a procedural category. However, it should be assumed that this concept is a category of substantive law, and in criminal law a victim acts as an independent participant in criminal legal relations.

Analysis and generalization of positions of the highest courts of Russian Federation allows us to determine the material nature of a victim.

Thus, the Constitutional Court of Russian Federation in its ruling dated January 18, 2005 No. 131-O "At the request of the Volgograd garrison military court on checking the constitutionality of part eight of Article 42 of Code of Criminal Procedure of Russian Federation" noted that according to the literal meaning of this provision (part 1 of Art. 42 Code of Criminal Procedure), the legal status of a person as a victim is established on the basis of his/her actual position: it is only procedurally formalized by a decision of the inquiry officer, investigator, prosecutor and court on recognition as a victim, but is not formed by it.

Subsequently, the Plenum of the Supreme Court of Russian Federation, in its Resolution No. 17 of June 29, 2010, "On the Practice of the Courts' Application of the Rules Regulating Participation of a Victim in Criminal Proceedings" expressed a similar point of view: "... the legal status of a person as a victim is established on the basis of his/her actual position and only procedurally formalized by a resolution, but not formed by it".

With regard to the topic under consideration, a representative of authorities as a victim should be recognized as a person who is in the state or municipal service, endowed in the manner established by federal laws and other regulatory legal acts of Russian Federation, laws and other regulatory legal acts of constituent entities of Russian Federation with administrative powers in relation to persons who are not in service dependence.

Moreover, the crime must cause physical, property and moral harm to this person. In addition, a victim (a representative of authorities) is an additional object of criminal encroachment. Thus, the material status of a victim is emphasized. In turn, in criminal law, he/she acts as an independent participant in criminal legal relations.

As part of the crime, a victim is a sign of the object of a crime, and in the mechanism of violation of public relations that characterize the object of the encroachment, the act is directed at him/her as a participant (subject) of public relations.

\section{Results}

An analysis of materials of judicial practice allows us to note that the courts of general jurisdiction do not have a definite position on whether a victim (a representative of the authorities) has the right to conciliation.

Moreover, Vinokurov V.N. notes that the non-differentiation of situations of harm in the field of public security and in the sphere of exercising powers in the administration of justice and administration leads to the fact that the courts are exempted from criminal liability in connection with reconciliation with a victim in the commission of crimes under Art. Art. 297, 319, part 1 of Art. 318 of Criminal Code of Russian Federation.

For example, in the Review of judicial practice in the termination of criminal cases by military courts in connection with reconciliation with a victim and active repentance, approved by a resolution of the Presidium of the Supreme Court of Russian Federation of 
June 1,2005 , it is noted that criminal and criminal procedure laws do not contain direct instructions prohibiting to terminate criminal cases on the so-called two-object crimes in connection with reconciliation with a victims, as well as cases in which a victim is absent. In this regard, some judges believe that this is possible and widely use this institution in their judicial practice.

In addition, in accordance with Art. 25 of the Code of Criminal Procedure of Russian Federation and 76 of the Criminal Code of Russian Federation, termination of the case is impossible in cases of two-object crimes, in which the criminal encroachment is also carried out on another object protected by law, by the nature of which the norms providing for these crimes are located in the relevant chapters of the Criminal Code of Russian Federation, and a victim acts only as an additional objective manifestation of these encroachments. In these cases, not only is it impossible to achieve reconciliation with the main object, but reconciliation with a victim does not eliminate the harm caused to this main object of criminal encroachment, which means that the crime as a whole does not lose its public danger and the criminal case against the person who committed it does not may be terminated.

However, further, a position is expressed that contradicts the above: "at the same time, it seems that if, in cases of" two-object "crimes, an encroachment on the main, priority object, due to its insignificance, can be recognized as formal, and reconciliation with a victim has been achieved, terminated for reconciliation with a victim. The court must motivate this decision in a resolution.

In part, the position set out in the review regarding the impossibility of reconciliation in two-object crimes, in which a victim is an additional object, the courts reflect this in the certificates, but when analyzing the information contained in the certificate, it can be seen from the terminated criminal cases that the district courts terminate cases on two-object crimes. For example (the information is indicated in the certificate), for 10 months of 2006 the courts of Chelyabinsk region 76 persons accused under Part 1 of Art. 318 of the Criminal Code of Russian Federation were released from criminal liability in connection with the reconciliation of the parties as well as 8 persons accused under Art. 319 of Criminal Code of Russian Federation.

The point of view about the impossibility of terminating criminal cases in connection with reconciliation with a victim in two-object crimes is supported by many higher courts of the constituent entities of Russian Federation [20]. But there are also courts of subjects that consider it possible to release persons from criminal liability in connection with reconciliation with a victim who committed crimes under Art. 319 of Criminal Code of Russian Federation.

When studying judicial practice in criminal cases initiated for crimes under Art. 318, 319 of the Criminal Code of Russian Federation and terminated in connection with the reconciliation of the parties, various motivations were identified in the motivation part of the decisions.

For example, in a ruling dated October 19, 2017, the Kirovsky District Court of St. Petersburg on charges of a defendant I., accused of committing crimes under Art. 319, part 1 of Art. 318 of the Criminal Code of Russian Federation, notes that the petition to terminate the criminal case against I. is subject to satisfaction, since I. has not previously been convicted, is accused of committing crimes of small and medium gravity, has reconciled with a victim, the victim has no material claims against him. Further, the court gives a positive characterization of the personality of the defendant. At the same time, the court does not take into account the arguments of the public prosecutor about the twocomponent object of criminal encroachment and the impossibility of terminating the criminal case on this corpus delicti in connection with the reconciliation of the parties. 
In addition, there are cases of termination of a criminal case in connection with the reconciliation of the parties for crimes under Part 1 of Art. 318 and Art. 319 of the Criminal Code of Russian Federation, with other motivations. For example, the Kalininsky District Court of Chelyabinsk, considered it possible in accordance with Art. 76 of the Criminal Code of Russian Federation to terminate the criminal case, since L. has no previous convictions, what he has done belongs to the category of crimes of average gravity, the harm from the deed has been smoothed out, reconciliation with the victim has been achieved.

The wording of the reasoning part of the decision of the Leninsky District Court of Samara on the termination of the criminal case in connection with the reconciliation of the parties of May 29, 2013 No.

The court did not recognize as convincing the arguments of the public prosecutor about the impossibility of terminating the criminal case against the defendant in connection with reconciliation with a victim, noting that the negative consequences of the act were expressed only in causing moral harm to the victim by the actions of the defendant. In turn, the victim petitioned to terminate the case for the reconciliation of the parties, and the encroachment on the second object - the established state management procedure in these specific circumstances, due to the insignificance of such an encroachment, is formal.

In all these cases, the court reacts negatively to the statements of the public prosecutor, who objected to the termination of criminal case, since the indicated elements of the crime also affect the interests of the state, and the court considers the above arguments untenable.

However, there are examples indicating that the state prosecutors consider it possible to terminate the criminal case under Art. 76 of the Criminal Code of Russian Federation. It should be noted the cassation ruling of the Judicial Collegium for Criminal Cases of Supreme Court of Russian Federation dated January 17, 2006 No. 53-O05-83, which notes that in accordance with Art. 76 of Criminal Code of Russian Federation, the release from criminal responsibility of a person who first committed a crime of little gravity is possible if he/she has made peace with a victim and made amends for the harm caused to the victim. It follows from this provision that such release is permissible only in cases of crimes that infringe on the legal rights and interests of specific persons who have suffered from crimes. Concealment of crimes committed in this case is a crime against justice. Exemption from criminal liability in connection with reconciliation with the victim in cases of this category is contrary to the meaning of law.

An absolutely opposite point of view was expressed in the cassation ruling of December 24, 2007 No. 22-14699 by the Judicial Collegium for Criminal Cases of Moscow City Court. The judicial board, having checked the case materials, having discussed the arguments of cassation presentation, notes that it is impossible to agree with the arguments of cassation presentation on the groundlessness of termination of criminal case (according to part 1 of article 116 of Criminal Code of Russian Federation and part 1 of article 318 of Criminal Code of Russian Federation), since the termination of criminal case against $\mathrm{K}$. in connection with reconciliation with the victim was made in accordance with specified requirements of law. It was decided taking into account the nature and degree of public danger of the crime committed, all the circumstances of the case and data on the personality of the accused. It is noted that $\mathrm{K}$. admitted guilt, repented of what he had done, made amends for the harm caused, reconciled with the victim before the start of the trial. The judicial board finds no violations of requirements of criminal procedure law, entailing the cancellation of judgment. The Criminal Procedure Code of Russian Federation does not contain prohibitions for dismissing the case on the grounds specified in the submission. In such circumstances, there are no grounds for canceling the court decision on the grounds of cassation presentation. 
Even more problems, in our opinion, to the issue of reconciliation with a victim are caused by the resolution of the Plenum of Supreme Court of Russian Federation of December 9, 2008 No. 25 "On judicial practice in cases of crimes related to violation of traffic rules and operation of vehicles, as well as their unlawful seizure without the purpose of theft", in paragraph 16 of which it is explained to the courts that termination of a criminal case on a crime under Art. 264 of Criminal Code of Russian Federation, for the reconciliation of parties (Art. 25 of Criminal Procedure Code of Russian Federation) is a right, not an obligation of court.

Thus, this decision is a reason for exemption from criminal liability of persons in connection with reconciliation with a victim who have committed two-object crimes, in which health and life are an additional object.

The resolution of the Plenum of Supreme Court of Russian Federation dated June 27, 2013 No. 19 "On the application by courts of legislation regulating the grounds and procedure for release from criminal liability" did not clarify the resolution of issue of possibility or impossibility of terminating criminal cases in connection with reconciliation with a victim (in two-object crimes). Clause 9 of this Resolution explains to the courts that when resolving the issue of exemption from criminal liability, specific circumstances of criminal case should also be taken into account, including the specifics and number of objects of criminal encroachment, their priority, the presence of a freely expressed will of a victim, changes in the degree of public danger of the person who committed the crime, after making amends for the harm and reconciliation with the victim, the identity of perpetrator, circumstances mitigating and aggravating the punishment.

Thus, there is no unequivocal answer on the issue of reconciliation in two-object crimes in judicial practice.

Perhaps this is also due to the contradictory data of Judicial Department at the Supreme Court of Russian Federation on the number of criminal cases terminated in connection with reconciliation with a victim.

It should be noted that in these data there are two criminal cases initiated under Part 2 of Art. 318 of Criminal Code of Russian Federation in 2012, and one criminal case initiated under Part 2 of Art. 318 of Criminal Code of Russian Federation in 2013, which were then terminated due to reconciliation with a victim, despite the fact that they belong to the category of serious crimes.

Moreover, at present, the practice of exemption from criminal liability (part 1 of article 318, article 319 of Criminal Code of Russian Federation) with the appointment of a court fine, which is provided for by art. 76.2 of Criminal Code of Russian Federation. At the same time, preliminary investigation bodies apply for the termination of criminal case and appointment of a criminal-legal measure in the form of a court fine.

\section{Discussion}

An analysis of provisions of regulatory legal acts, court decisions and scientific points of view makes it possible to establish that a victim, as a participant in criminal legal relations, has a criminal legal status, the manifestation of which is the granting of the right to consent to reconciliation with the person who committed the crime.

S.N. Shatilovich notes that the peculiarity of release from criminal liability in connection with reconciliation with a victim (and the criminal procedural basis for terminating the criminal case - Article 25 of the Code of Criminal Procedure of Russian Federation) lies in the fact that the legislator transfers at the discretion of a victim not an assessment of the degree of public danger of the crime committed, but the question of how to resolve the conflict that has arisen [4]. 
In this regard, the question arises about the possibility of reconciliation for all crimes in which there is a victim. It should be noted that this issue is controversial both in the scientific field and in law enforcement practice. A number of authors believe that exemption from criminal liability in connection with reconciliation with the victim is possible in all cases falling under the requirements of Art. 76 of the Criminal Code of Russian Federation. For example, the authors of the Commentary to the Criminal Code of Russian Federation, edited by M.V. Lebedeva believe that exemption from criminal liability in connection with reconciliation with a victim is provided for by the Criminal Code of Russian Federation for all crimes belonging to the category of small or medium severity.

12000

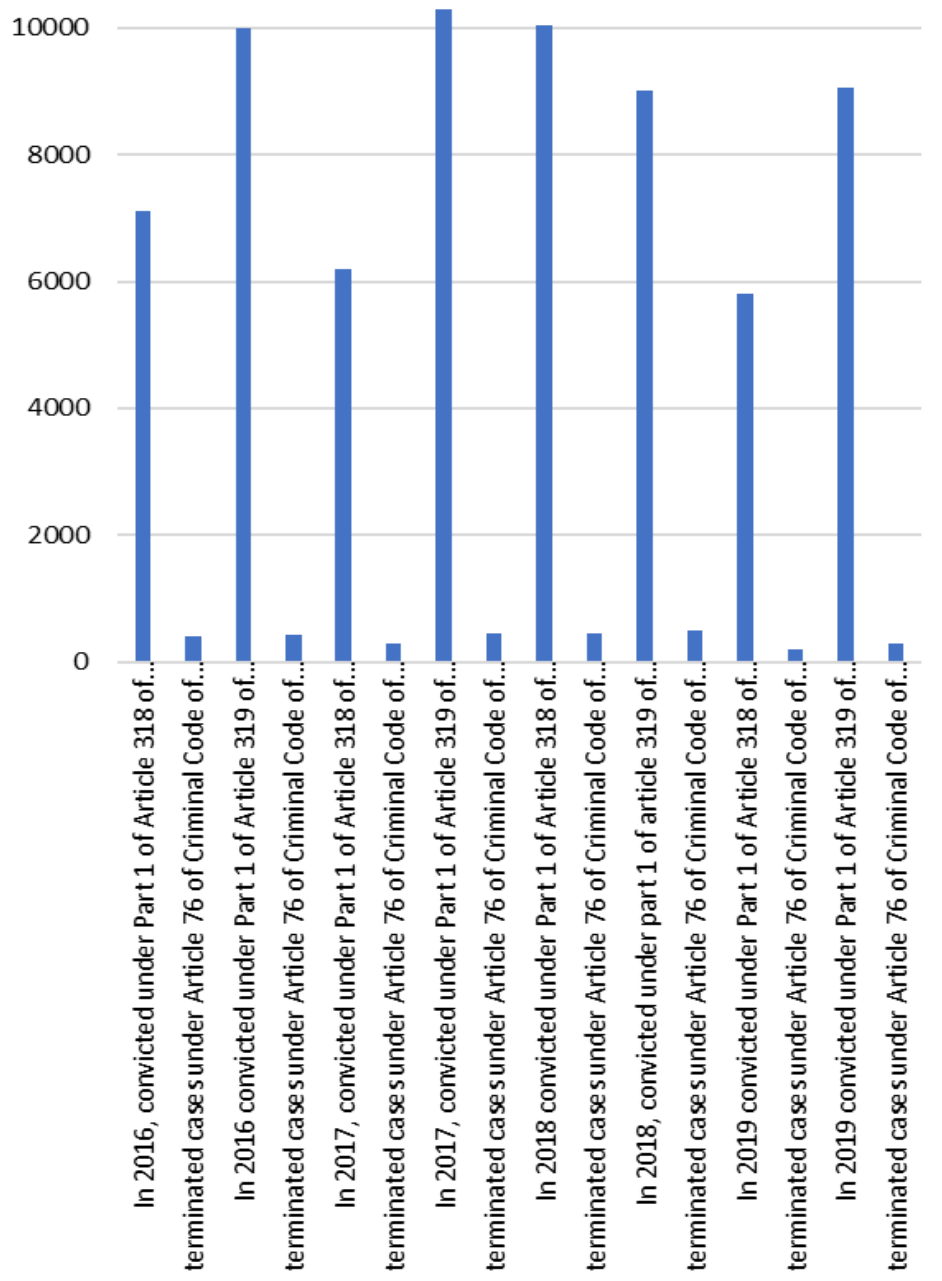

Fig. 1. Statistics.

In the Comments to the Criminal Code of Russian Federation, edited by A.I. Raroga the author notes that Art. 76 of the Criminal Code of Russian Federation allows one to release from criminal liability in connection with reconciliation with a victim of the accused or suspect in any crime of small and medium gravity committed for the first time. The authors 
of the Commentary to the Criminal Code of Russian Federation, edited by V.I. Radchenko and A.S. Mikhlin, express a similar point of view, according to which exemption from criminal liability in connection with reconciliation with a victim can be applied to a much wider range of persons - to all persons who have committed crimes of small or medium gravity, i.e. intentional acts, for the commission of which the maximum punishment provided for by the Criminal Code of Russian Federation does not exceed five years in prison, or the law provides for a lighter punishment, or if the act was committed through negligence. V.A. Davydov claims that Art. 76 of the Criminal Code of Russian Federation does not directly provide for any restrictions on the release of a person from criminal liability depending on the object of a crime, therefore, the provisions of this article apply to a person who has committed a two-pronged crime (for example, contempt of court - part 1 of article 296 of the Criminal Code of Russian Federation) ... If harm is caused only to the interests of society or the state and there is no victim in the criminal procedural sense, then the provisions of Art. 76 of the Criminal Code of Russian Federation cannot be applied.

An interesting position is expressed by E.L. Sidorenko, noting that in an effort to maximally ensure the rights of a victim - an individual, the law enforcement officer neglects the public and state interests to which the criminal encroachment is directed. Based on the literal interpretation of Art. 25 of the Code of Criminal Procedure of Russian Federation, in order to terminate a criminal case, it is necessary that the parties reach reconciliation. Since both a victim and a prosecutor are parties to criminal proceedings on the part of prosecution, not only the will of a victim, but also the consent of a public prosecutor, is required to terminate the case. Although, in fact, the absence of a victim is not an obstacle to the termination of the case, which, in essence, infringes upon the interests of the state in restoring public rights. In addition, the scientist further notes that the public interests of the state are to preserve the rule of law and order and public safety, and their provision involves criminal prosecution. At the same time, being guided by the principle of justice and taking into account the fact that a perpetrator compensated for the harm caused to the person as an additional object, the court may decide to terminate the criminal case if public interests are ensured.

At the same time, there are statements by authors who hold a different point of view. For example, A.P. Anisimov notes that criminal cases on crimes against public safety and public order or against state power (the so-called two-object crimes) cannot be terminated due to the reconciliation of parties, since reconciliation with a victim in cases of crimes against justice contradicts the meaning of the law, which protects interests from criminal encroachment. In this case, an individual who has suffered from criminal acts is harmed only because this person is a representative of authorities and performs certain official duties. Consequently, his/her declaration of will to dismiss the case in connection with reconciliation with the accused has no legal significance.

This position is shared by D. Garbatovich, who notes that court decisions on the termination of criminal cases in connection with the reconciliation of parties against the defendants in cases of such crimes as hooliganism committed with the use of weapons or objects used as weapons, the use of violence against a government official; insulting a government official are controversial.

\section{Conclusion}

In connection with the foregoing, we believe that for crimes in which the main object is the interests of the state, and a victim is an additional objective manifestation of the encroachment (which is inevitably harmed when the main object is attacked), it is impossible to achieve reconciliation with the main object of encroachment, since the mechanisms of compensation have not been developed, expressed in undermining the 
authority. In addition, reconciliation with a victim will not be able to eliminate the harm caused to the main object of criminal assault. Consequently, the committed crime in its objective manifestation does not lose public danger, and the criminal case against the person who committed it cannot be terminated.

We must agree with R.M. Minulin, noting that the categories of crimes for which reconciliation is possible are indicated in law insufficiently. For crimes, the object of which is not only a person or property, but also public order and security, public health and public morality, etc., the participation of a victim in the case does not exclude the fact that these crimes pose a threat to the population as a whole, not only individuals.

It seems that in this case the "dispositive principles" in the Criminal Code of Russian Federation, expressed, in particular, in the legal activity of a victim in reconciliation with the culprit, are limited by the public interests of the state.

In order to exclude the indicated contradictory law enforcement practice in the scientific community, the following solutions to this problem are proposed.

For example, S.V. Sinenko proposes to exclude such situations from judicial practice a special procedure for implementation of a victim's right, provided for in Art. 25 of Code of Criminal Procedure of Russian Federation, for the analyzed category of criminal cases. The specificity of this order will lie in the agreed decision of a specific victim of an individual and the state institution in which he/she serves or works. The decision of the employee to reconcile with the defendant, and in case of termination at the stage of preliminary investigation - with the accused or suspect, is mandatory. However, it is not enough. In this case, the state body is obliged to express its opinion on the possibility or impossibility to forgive the guilty person for the act committed. The decision of a state body should be collegial and discussed, for example, at operational meetings with the head of this body. Further, the author proposes Art. 25 of Code of Criminal Procedure of Russian Federation shall be supplemented with the following part: "For crimes under Part 1 of Art. 212, Art. 294-298, 304, 309, 311, 317-320, part 2 of Art. 321, Art. 333, 334, part 2 of Art. 336 of Criminal Code of Russian Federation, a criminal case can be terminated only with the consent of the body in which the victim was appointed to the position in accordance with the established procedure and performed the duties stipulated by the job descriptions for this position when committing these crimes."

This position seems controversial, since a specific state institution, for example, a territorial body of internal affairs for a constituent entity of Russian Federation, cannot express the interests of the entire system of Ministry of Internal Affairs of Russia or the entire state.

According to E.L. Sidorenko, in order to improve the investigative and judicial practice, amendments to the criminal and criminal procedural legislation are not required, but a change in the angle of view on the assessment of legal nature of reconciliation and status of its participants is proposed, which, according to the scientist, should ensure consistency of norms of criminal and criminal procedural legislation in the assessment of a victim and create a reliable basis for the development of media technologies in public law.

In this regard, we consider it expedient to establish a ban on exemption from criminal liability in connection with reconciliation with a victim in cases where a perpetrator has committed a crime against justice or the order of administration, in which the victim is "special" (a representative of the authorities, including an employee of the internal affairs). Accordingly, Article 76 of Criminal Code of Russian Federation should be supplemented with part 2 of following content:

" 2 . The provisions of part 1 of this article do not apply to persons who have committed crimes against justice and the order of administration."

In addition, it is necessary to make an appropriate addition to the resolution of the Plenum of Supreme Court of Russian Federation dated June 27, 2013 No. 19 "On the 
application by courts of legislation regulating the grounds and procedure for exemption from criminal liability." An example of such an approach is the resolution of the Plenum of Supreme Court of Republic of Belarus of March 29, 2012 No. 1 "On the practice of applying by courts Articles 86, 88, 89 of Criminal Code of Republic of Belarus, providing for the possibility of releasing a person from criminal liability", according to which, if a person has committed a crime that encroaches on several objects of criminal law protection at once (for example, when committing acts under Part 1 or Part 2 of Article 339 of Criminal Code, along with public order, also on the health or property of a citizen), release of the accused from criminal liability under Art. 89 of Criminal Code is not excluded. However, the court, when deciding on the release of the accused from criminal liability, should, in order to ensure the protection of interests of both the victim and the state and society, take into account the social danger of consequences that have occurred for each object of criminal encroachment (clause 8).

\section{References}

1. A.V. Sumachev, Legal Science and Law Enforcement Practice 1, 66-79 (2008)

2. O.A. Vladimirova, Bulletin of the Samara Law Institute, 26-30 (2019)

3. E.L. Sidorenko, Russian investigator 9, 44-46 (2011)

4. S.N. Shatilovich, Legal Science and Law Enforcement Practice 1, 54-62 (2011)

5. E. Sidorenko, Criminal law 3, 49-57 (2011)

6. A.P. Anisimov, Legality 10, 43-45 (2009)

7. D. Garbatovich, Criminal law 2, 34-35 (2014)

8. V.N. Vinokurov, Legality 6, 52 - 55 (2019)

9. S.V. Sinenko, Russian investigator 12, 24-26 (2011)

10. A.V. Kopytova, N.S. Zotkina, I.G. Reshetnikova, MATEC Web of Conferences 239, 04012 (2018) DOI: 10.1051/matecconf/201823904012

11. V. Lez'Er, N. Semeryanova, A. Kopytova, I. Kvach, E3S Web of Conferences 110, 02094 (2019) DOI: 10.1051/e3sconf/201911002094

12. Y.V. Truntsevsky, I.I. Lukiny, A.V. Sumachev, A.V. Kopytova, MATEC Web of Conferences 170, 01067 (2018) DOI: 10.1051/matecconf/201817001067

13. M.S. Gusarova, A.V. Kopytova, I.G. Reshetnikova, Periodico Tche Quimica 16(31), 903-912 (2019)

14. Y. Truntsevsky, V. Lez'er, S. Belyasov, A. Kopytova, E3S Web of Conferences 157, 03016 (2020) 